\title{
学術・技術論文
}

\section{ZMP-重心モデルと台車型倒立振子モデルのアナロジーによる， ヒューマノイドロボットの高機動化制御}

\author{
杉 原 知 道*1 中 村 仁 彦*1*2
}

\section{High Mobility Control of Humanoid Robots Based on an Analogy of ZMP-COG Model and Carted Inverted Pendulum Model}

\author{
Tomomichi Sugihara $^{* 1}$ and Yoshihiko Nakamura*1*2
}

\begin{abstract}
A new control of the whole-body motion of humanoid robots is proposed. An analogy of ZMP-COG model and carted inverted pendulum represents the core dynamics of humanoids as strong nonlinear systems. It clues to the ZMP manipulation with a large number of degrees-of-freedom in the whole-body cooperated, and to the technique of a direct handling of dynamical constraints about the reaction force from the environment. As the result, the robot body is controlled just as if it were a simple inverted pendulum. And, COG Jacobian maps the motion of such an approximate model to the real multibody system. The advantage of proposed typically appears in the robustness against large perturbations, since it is suitable for a realtime implementation with a less computational cost.
\end{abstract}

Key Words: Humanoid Robot, Legged Motion Control, ZMP-COG Model, Carted Inverted Pendulum Model

1.はじめに

ヒューマノイドロボットの研究が現在盛んな理由には，その 形態が人間に合わせて作られたインフラ内での活動に適してい るために，将来的に我々を身近で支援する新たなツールとして の可能性が注目されている [1] ということも確かにある. しか し恐らくそれ以上に強いのは，人並，あるいはそれを超える運 動能力を持ち得るという期待であろう.

ヒューマノイドは，慣性系に固定された点を持たず，かつ運動 に伴って接地状態が推移しリンク構造が変化する [2]. これらの 性質のために強い非線形性を有する系であり，その制御問題に は原理的に閉じた解が存在しない。この困難な問題に対して現 在多くとられている解は, 障害物の回避や力学的整合性の維持 といった拘束条件を考慮しつつ, タスクを遂行する運動軌道を あらかじめ用意しておき，そ机を関節角制御によって奏ロボット に再現させるいわゆるパターンベーストな方法である [3]～[8]. このアプローチでは, 逆動力学解析等を併用し, 目標值生成の 段階で複雑な問題の大部分を解決する. 安定化制御器は基本的 にその目標軌道を再現すればよく，機能が貧弱であってもある 程度のタスク遂行には問題ない. しかしこの方法が有効なのは,

原稿受付 2004 年 11 月 8 日

${ }^{* 1}$ 東京大学大学院情報理工学系研究科

$* 2$ 科学事業振興事業団戦略的基礎研究推進事業

${ }^{* 1}$ Univ. of Tokyo

*2 Japan Science and Technology Corporation, CREST Program
環境について事前に十分な情報が得られており，外乱が小さい 場合にとどまる．予測不可能な要素に富む環境を想定したとき にロボットに要求される, 物体との衝突や動作指令の急变更等 の咄哮の状況に対応できるような高い機動性は期待し難い.人 間においても，加速度レベルまで目標軌道に従うことが運動能 力の向上につながるとは考えにくく，高機能な制御器の働きに よって初めて高い機動性が実現されると考えるべきであろう.

Gubina ら [9] は, 極配置法を応用した 2 脚モデルのダイナ ミックな運動制御法を開発したが，モデルが単純過ぎ，実際のロ ボットへの適用には課題が多かった。宮腰ら [10] は振動パター ン生成素子である CPG を用いて，環境と相互作用する身体の 適応的な振舞いをシミュレートした。これは人間における低次 神経系の機能再構成が目的であり，実用性の議論はしていない。 Pratt ら [11] はロボットの内部モデルと環境モデルとを仮想的 なばね・ダンパで結合することにより，外乱に対し頑健な歩行制 御を実現したが, 力学的な制約を考慮しておらず, 緩慢な動作 のみ検証している．藤本・河村 [12] は，二次計画法によって決 定した目標值に従って床反力を直接制御する方法を開発し, シ ミュレーションでその機能を示したが, 提案された床反力制御器 は即応的な運動への適用に限界がある. 池田ら [13] は, 力学的 な拘束条件と制御目的に沿う人為的な拘束条件とを脚型ロボッ 卜の接地状態によって切り換える可变拘束制御を提案し, 矢状 面内に拘束された 1 足および 2 足ロボットの走行運動や， 4 足 ロボットの三次元走行等を実現した。これは厳密な運動方程式 を必要とするため, 大自由度なロボットの場合に計算コストが 
深刻な問題となる。このように，上記の研究のいずれにおいて も，実装上の問題も含め，ロボットのダイナミクスの複雑さが 障害となっている.

ところが, 複雑に見えるヒューマノイドのダイナミクスも, 重 心と外力との関係を抽出した比較的単純なモデルによってその 本質的特性を表すことができる，すなわち，外力の床面上の作 用点重心まわりに発生するモーメントの水平成分がゼロとなる (この点は Zero Moment Point, ZMP [14] と呼ばれる)こと から，重心を先端質量，ZMP を支持点に見立てた台車型倒立 振子にたとえられるダイナミクスを有することが分かる。本稿 ではこの比喻に基づいた，ZMP 操作によるヒューマノイドの 全身運動制御法を提案する。これは次のような効果を持つ.

（1）ZMP を操作量とすることで，環境との接地状態によって 決まる力学的制約条件を直截的に考慮することができる.

（2）よく知られる倒立振子の制御と同じ原理によってヒューマ ノイドのダイナミックな運動を実現できる。

（3）各リンクの局所的なダイナミクスを無視し, 系全体の大局的 ダイナミクスをとらえることで，計算コストを抑えられる。 ZMP を操作量と見なして重心制御を行う方法はいくつか提案 されている. 空尾ら [15] による, ファジィ制御を用いて ZMP を操作し重心を制御する方法は，いわばファジィ制御によって 倒立振子を立たせるのと同じ試みであり，解決方法としては不 適切である.小幡ら [16]の方法は, 立脚状態においてZMPを 操作し重心位置を制御するもので, 移動動作への拡張はなされ ていない. 竹内 [17] は Receding Horizon 制御を応用し, 重心 加速度と ZMP を同時に入力量としてリアルタイムに決定する 方法を提案しているが，両者の関係が明確でなく，現象を理解 し難い. 水戸部ら [18] は，無質量脚ロボットモデルの重心を定 常的な直進運動に収束させる ZMP 操作量の決定方法を示した が，多リンク系への有効な拡張はいまだ見出せていない．

提案する方法は, 倒立振子という比喻に基づいて脚運動系の 制御戦略を立てるものである. 加藤 [19] や有本・宮崎 [20] が述 べたように，従来この比喻は制御系設計に扔いて定性的な指針 を与えるにとどまっていたが, 本稿ではある程度定量的にこれ を利用する。 また，重心ヤコビアン [21]を用いた一般的な多り ンク型脚ロボットに適用する方法についても述べる。

\section{2. 倒立振子モデル型 ZMP 操作法}

Fig. 1 (a) に示すようなヒューマノイドロボットの厳密なダ イナミクスは，次の運動方程式で表される [12].

$$
\left[\begin{array}{ll}
\boldsymbol{H}_{11} & \boldsymbol{H}_{12} \\
\boldsymbol{H}_{21} & \boldsymbol{H}_{22}
\end{array}\right]\left[\begin{array}{c}
\ddot{\boldsymbol{q}}_{0} \\
\ddot{\boldsymbol{\theta}}
\end{array}\right]+\left[\begin{array}{l}
\boldsymbol{b}_{1} \\
\boldsymbol{b}_{2}
\end{array}\right]=\left[\begin{array}{l}
\mathbf{0} \\
\boldsymbol{\tau}
\end{array}\right]+\sum_{k=1}^{N}\left[\begin{array}{ll}
\boldsymbol{K}_{k 11} & \boldsymbol{K}_{k 12} \\
\boldsymbol{K}_{k 21} & \boldsymbol{K}_{k 22}
\end{array}\right]\left[\begin{array}{c}
\boldsymbol{f}_{k} \\
\boldsymbol{n}_{k}
\end{array}\right]
$$

ただし $\ddot{\boldsymbol{q}}_{0}$ は慣性系に固定されていない基底リンク（一般に体

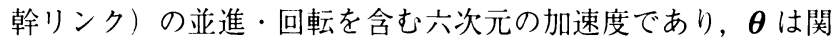
節角ベクトル, $\boldsymbol{H}_{i j}$ は慣性行列, $\boldsymbol{b}_{i}$ は遠心力, コリオリ力, 重 力を含む項， $\boldsymbol{\tau}$ は関節駆動トルク， $N$ はロボットと環境との接 触点の数, $\boldsymbol{f}_{k}$ および $\boldsymbol{n}_{k}$ は $k$ 番目接触点において作用する外 力拉よびモーメント， $\boldsymbol{K}_{k i j}$ は外力を一般化力に変換する行列で

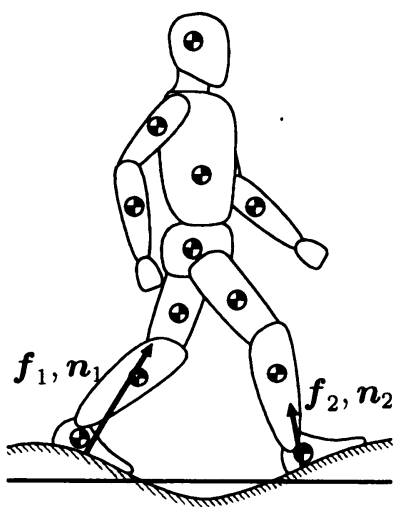

(a) Precise anthropomorphic model

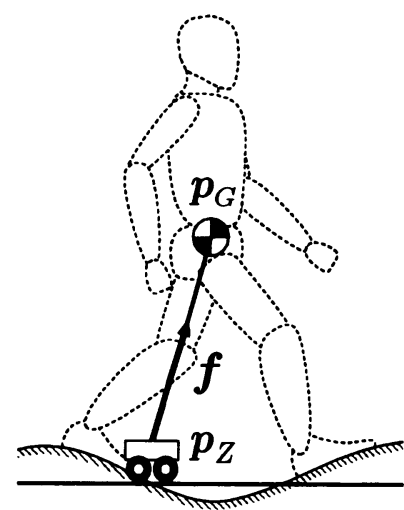

(b) Inverted pendulum metaphorized model
Fig. 1 An inverted pendulum metaphore for biped robot

ある。この式から，基底リンクの 6 自由度を直接駆動する一般 化力が存在しないために，全身連動のためには内力 $\tau$ を環境と の相互作用を通して外力 $\boldsymbol{f}_{k}$ および $\boldsymbol{n}_{k}$ へと変換しなけ机ばな らないということが読み取れる。しかし $\boldsymbol{H}_{i j}$ などはそれ自体が 大規模で複雑な形をとるため, $\boldsymbol{\tau}$ と $\boldsymbol{f}_{k}, \boldsymbol{n}_{k}$ との関係を直感的 に把握するのは困難なうえに, 計算量の観点からも, 高速な計 算がリアルタイムに要求される運動制御器の実装において障害 となる。これらの理由から，式（1）をそのまま制御に用いるこ とは不利である. しかし, 式（1）の上段（駆動力が０の行）か ら並進運動に関する部分を抜き出し, 各リンクの局所的な運動 ではなく系全体の大局的な運動に着目すると, 次のような単純 な方程式と等価であることが分かる。

$$
\sum_{i=0}^{n-1} m_{i}\left(\ddot{\boldsymbol{p}}_{G, i}+\boldsymbol{g}\right)=\sum_{k=1}^{N} \boldsymbol{f}_{k} \Leftrightarrow m\left(\ddot{\boldsymbol{p}}_{G}+\boldsymbol{g}\right)=\boldsymbol{f}
$$

ただし $n$ はリンクの数（基底リンクをリンク 0 とする）, $m_{i}$, $m$ はそれぞれリンク $i$ およびロボット全体の質量, $\boldsymbol{p}_{G, i}, \boldsymbol{p}_{G}=$ $\left[\begin{array}{lll}x_{G} & y_{G} & z_{G}\end{array}\right]^{T}$ はそれぞれリンク $i$ およびロボット全体の重心, $\boldsymbol{g}$ は重力加速度, $\boldsymbol{f}=\left[\begin{array}{lll}f_{x} & f_{y} & f_{z}\end{array}\right]^{T}$ は系全体に作用する外力 の総和である。一方, 式 (1) の上段のうち回転運動に関する部 分は, 環境から受ける外力によるモーメントと重心まわりの慣 性力によるモーメントとの平衡の式として, 次のようにまとめ ることができる.

$$
\boldsymbol{n}_{G}=\left(\boldsymbol{p}_{Z}-\boldsymbol{p}_{G}\right) \times \boldsymbol{f}+\boldsymbol{n}_{Z}
$$

ただし $\boldsymbol{n}_{G}$ は重心まわりに働く慣性力によるモーメント, $\boldsymbol{p}_{Z}=$ $\left[\begin{array}{lll}x_{Z} & y_{Z} & z_{Z}\end{array}\right]^{T}$ は地面上のある点で, $\boldsymbol{n}_{Z}$ は環境から受ける $\boldsymbol{p}_{Z}$ まわりの全外モーメントである。 $\boldsymbol{p}_{Z}$ のとり方は一般的には任 意だが，今これを， $n_{Z}$ が重力方向と平行になるように選ぶこ とにする。このような $\boldsymbol{p}_{Z}$ が ZMP である。簡単のために重力 加速度方向に $z$ 軸を, 水平面内に $x, y$ 軸をそ机ぞ机互いに直 交する方向に定めると, ZMP の定義より $\boldsymbol{n}_{Z}$ の $x, y$ 成分は共 にゼロであり, さらに系全体の運動への $n_{G}$ の寄与が重心の並 進運動の影響と比較して十分小さいと仮定すれば，Fig. 1 (b)に 
示すような，重心に全質量が集中し ZMP を支持点とする台車 型の倒立振子と等価なダイナミクスを有する。また式 $(2)$ ，(3) の各成分を書き下せば，次式が成り立つ。

$$
\begin{aligned}
\ddot{x}_{G} & =\omega^{2}\left(x_{G}-x_{Z}\right) \\
\ddot{y}_{G} & =\omega^{2}\left(y_{G}-y_{Z}\right) \\
\ddot{z}_{G} & =\frac{f_{z}}{m}-g
\end{aligned}
$$

ただし $z_{Z}$ は床面の高さ (既知)， $g$ は重力加速度の絶対值であ り, $\omega^{2}$ は次のように定義した。

$$
\begin{aligned}
\omega^{2} & \equiv \frac{\ddot{z}_{G}+g}{z_{G}-z_{Z}} \geq 0 \\
\left(\because \quad \ddot{z}_{G}\right. & \left.\geq-g, \quad z_{G}>z_{Z}\right)
\end{aligned}
$$

ここで, 重力方向の運動を表す式（6）に基づき，垂直床反力 $f_{z}$ の仮の目標值 ${ }^{r e f} f_{z}$ を次式のような PID 制御によって仮に 定める.

$$
\begin{aligned}
{ }^{r e f} f_{z}= & P_{z}\left({ }^{e f} z_{G}-z_{G}\right)+I_{z} \int\left({ }^{e f} z_{G}-z_{G}\right) d t \\
& +D_{z}\left({ }^{r e f} \dot{z}_{G}-\dot{z}_{G}\right)
\end{aligned}
$$

この ${ }^{r e f} f_{z}$ を式 (6) の $f_{z}$ に代入しラプラス変換すると, 次式 のようになる.

$$
\begin{aligned}
m s^{2} Z_{G}= & \left(P_{z}+\frac{I_{z}}{s}+D_{z} s\right)\left({ }^{r e f} Z_{G}-Z_{G}\right)-\frac{m g}{s} \\
\Leftrightarrow \quad Z_{G}= & \frac{D_{z} s^{2}+P_{z} s+I_{z}}{m s^{3}+D_{z} s^{2}+P_{z} s+I_{z}}{ }^{r e f} Z_{G} \\
& -\frac{m g}{m s^{3}+D_{z} s^{2}+P_{z} s+I_{z}}
\end{aligned}
$$

$P_{z}, I_{z}, D_{z}$ がすべて正かつ $m I_{z}-P_{z} D_{z}>0$ ならばこれは 安定であり, ${ }^{r e f} z_{G}=$ const. とすると, 最終值定理より $z_{G}$ が ${ }^{\text {ref }} z_{G}$ に収束することが示される。

$$
\lim _{t \rightarrow \infty} z_{G}=\lim _{s \rightarrow 0} s Z_{G}={ }^{r e f} z_{G} \quad\left(\because{ }^{r e f} Z_{G}=\frac{r e f}{s} z_{G}\right)
$$

この制御によって $z_{G}$ が $^{r e f} z_{G}$ に十分速く収束し, 水平方向の 運動と比較して $\ddot{z}_{G}$ が無視できるならば, $\omega^{2}$ はほほ定数と見な せる．このとき式 (4)，(5) は，付録 A で導出される倒立振子 の運動方程式と一致し，このことからも両者の類似性が分かる.

脚型ロボットを車輪型ロボットと同じように移動速度を指令 として操縦することを意図し, 重心の水平方向の運動について は速度 $\boldsymbol{v}_{G}=\left[\begin{array}{lll}v_{G x} & v_{G y} & v_{G z}\end{array}\right]^{T}$ の $x, y$ 成分に関する目標値 ${ }^{r e f} v_{G x},{ }^{r e f} v_{G y}$ を指令值とする，以降では式 (4)，(5) の対称 性より， $x$ 軸方向の運動についてのみ考える.式 (4)を 1 階微 分すると次式を得る.

$$
\ddot{v}_{G x}=\omega^{2}\left(v_{G x}-v_{Z x}\right)
$$

ただし $v_{Z x} \equiv \dot{x}_{Z}$ とした. 式 $(11)$ は, $v_{Z x}$ を入力とすれば $v_{G x}$ を制御できることを意味しており，これは倒立振子支持点の速 度と等価な力学的意味を持つので，その操作量決定には倒立振
子制御と同様の方法を適用することが可能である.

倒立振子は PID 制御や最適レギュレータ, $H_{\infty}$ 制御など様々 な方法で制御できることが知られている。ここでは簡単のため PID 制御を採用し，まず仮に $v_{Z x}$ を次式のように決める.

$$
\begin{aligned}
v_{Z x}= & P_{x}\left({ }^{e f} v_{G x}-v_{G x}\right)+I_{x} \int\left({ }^{r e f} v_{G x}-v_{G x}\right) d t \\
& +D_{x}\left({ }^{e f} \dot{x}_{G}-\dot{x}_{G}\right)
\end{aligned}
$$

ただし $P_{x}, I_{x}, D_{x}$ はそれぞれ比例・積分・微分ゲインである. 式（11）において， $\omega^{2}$ は実際には重力方向の運動によって変化

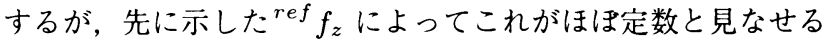
とし, 式 (12) を代入してラプラス変換すると, 次式を得る.

$$
V_{G x}=\frac{-\omega^{2}\left(D_{x} s^{2}+P_{x} s+I_{x}\right)}{s^{3}-\omega^{2} D_{x} s^{2}-\omega^{2}\left(P_{x}+1\right) s-\omega^{2} I_{x}}{ }^{r e f} V_{G x}
$$

Hurwitz の安定判別法より $P_{x}, I_{x}, D_{x}$ がすべて負であり，か つ $\omega^{2} D_{x}\left(P_{x}+1\right)+I_{x}<0$ を満たすとき安定である.また ${ }^{r e f} v_{G x}=$ const. とすると, 最終值定理より $v_{G x}$ が $^{r e f} v_{G x}$ に 収束することが示される。

$$
\lim _{t \rightarrow \infty} v_{G x}=\lim _{s \rightarrow 0} s V_{G x}={ }^{r e f} v_{G x} \quad\left(\because{ }^{r e f} V_{G x}=\frac{r e f}{s} v_{G x}\right)
$$

$y$ 軸方向についても同じように $v_{Z y} \equiv \dot{y}_{Z}$ を仮に決める。これ を 1 階積分すれば, ZMP の仮の目標位置 ${ }^{r e f} \boldsymbol{p}_{Z}$ が得られる.

$$
\begin{aligned}
& { }^{\text {ref }} x_{Z}=x_{Z}+\int_{\Delta t} \dot{x}_{Z} d t \\
& { }^{\text {ref }} y_{Z}=y_{Z}+\int_{\Delta t} \dot{y}_{Z} d t
\end{aligned}
$$

ただし $\Delta t$ は制御周期であり，実際にはこの間 $\dot{x}_{Z}, \dot{y}_{Z}$ が定数 であると見なしてオイラー積分を用いる。

脚型ロボットは慣性系に固定された点を持たないため, 足と 地面との各接触点において引っ張り方向に力を加えることがで きない．このことから，(i）垂直床反力が非負であり，かつ（ii） ZMP が支持領域内部に存在する，という条件を満たす必要があ る.そこで，上記の方法によって仮に決めた ${ }^{\text {ref }} f_{z},{ }^{\text {ref }} \boldsymbol{p}_{Z}$ に対 し（i），(ii）が満たされるように, ${ }^{r e f} f_{z}$ がある正の值 ${ }^{m i n} f_{z}$ を 下まわった場合にはこれを ${ }^{\min } f_{z}$ で置き換え，また Fig. 2 に示 すように, ${ }^{r e f} \boldsymbol{p}_{Z}$ が支持領域の外に出てしまった場合にはこれ を支持領域内の最近傍点で置き換えることにする。このような 置き換えを行った結果, 新たな ${ }^{r e f} f_{z}$ や $^{r e f} \boldsymbol{p}_{Z}$ によって系を安 定化できるかどうかは定かではなく，場合によってはこのまま では転倒につながる，大局的な安定性を保証するためには，地 形やロボットの足先形状を考慮して足を適切に踏みかえ, 支持 領域を能動的に変形しなければならない.さらにその間, 誤差 の蓄積により積分項が増大し, 支持領域が拡大した瞬間に大加 速が生じるおそれもある。 4 章のシミュレーションではこの問 題に対して特別な対策は行っていないが，より実際的には，ア ンチリセットワインドアップ機能などの併用が望まれる．本稿 


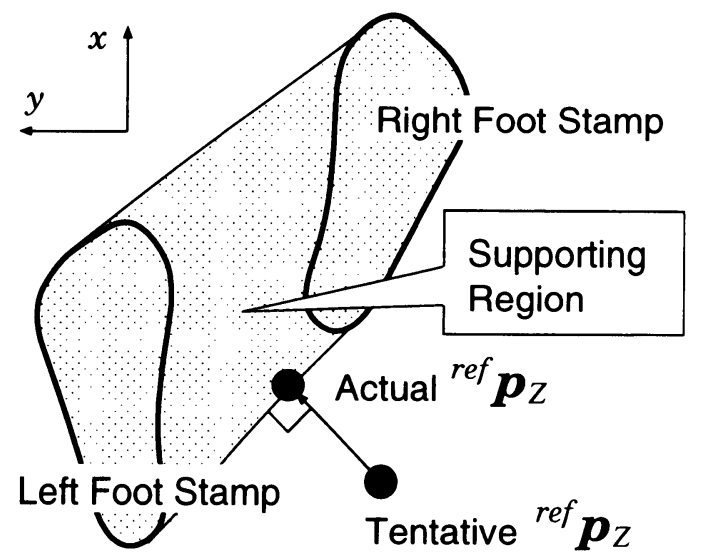

Fig. 2 Feasible area of the referential ZMP

ではこれらの問題についてこれ以上の議論はしない．

実際にはロボットは，水平な床の上だけではなく勾配や凹凸 を持った地面，また机・壁などの環境と三次元的に接触しなが ら運動する。このような状況に対応するために，付録 B で述べ るVHP の概念を用いる。

\section{3. 全身協調運動による間接的外力操作}

\section{1 等価重心加速度}

前章の冒頭にて述べた通り，ロボットの各関節に衝く内力（関 節トルク）とその反作用によって環境から受ける外力との厳 密な関倸は複雑で直感的には理解しづらく, 厳密な運動方程式 （1）に基づいて制御系を設計することは難しい。しかし，全リ ンクの幾何学的な関係から何らかの方法で重心加速度を直接 操ることができるならば，式（2）より，それは間接的に外力 を操作しているのと等価であると言える。この等価重心加速 度 ${ }^{r e f} \ddot{\boldsymbol{p}}_{G}$ は, 前章で述べた方法によって決定した ${ }^{r e f} f_{z}$ および

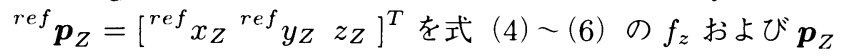
に代入することで得られる.

$$
\begin{aligned}
{ }^{r e f} \ddot{x}_{G} & ={ }^{r e f} \omega^{2}\left(x_{G}-{ }^{r e f} x_{Z}\right) \\
{ }^{r e f} \ddot{y}_{G} & ={ }^{r e f} \omega^{2}\left(y_{G}-{ }^{r e f} y_{Z}\right) \\
{ }^{r e f} \ddot{z}_{G} & =\frac{{ }^{r e f} f_{z}}{m}-g
\end{aligned}
$$

ただし ${ }^{r e f} \omega^{2}$ は次のように定義した。

$$
{ }^{r e f} \omega^{2} \equiv \frac{r e f}{z_{G}+g} \geq 0
$$

次節以降ではこのような考え方に基づき, 筆者らの提案する重 心ヤコビアン [21] の計算法と, これを用いた全身の協調運動に よる間接的外力操作方法について述べる.

\section{2 重心ヤコビアン}

重心 $\boldsymbol{p}_{G}$ は一般的に, 支持脚足裏の面接地状態が維持されて いる下では全関節角 $\boldsymbol{\theta}$ の関数 $\boldsymbol{p}_{G}(\boldsymbol{\theta})$ として表せる。したがっ て, 次式を满たすようなヤコビアン $\boldsymbol{J}_{G}$ が存在する.

$$
\dot{\boldsymbol{p}}_{G}=\boldsymbol{J}_{G} \dot{\boldsymbol{\theta}}
$$

ただし

$$
\boldsymbol{J}_{G} \equiv \frac{\partial \boldsymbol{p}_{G}}{\partial \boldsymbol{\theta}}
$$

この $\boldsymbol{J}_{G}$ を重心ヤコビアンと呼ぶ. $\boldsymbol{J}_{G}$ は一般的に, 複雑な非 線形多変数関数となる. その計算方法は平野ら [22], 田宮ら [23] も示しているが，前者はロボットを床面に固定された直鎖りン クとしてモデル化しており, 脚型ロボットのものとしては単純 すぎる, また後者は数值的な擬似勾配を用いるために, 計算量 が大きく精度も低いという久点がそれぞれあった。ここでは，任 意の剛体リンク系で表される脚型ロボットモデルにおいて，こ れを比較的高速に, かつ厳密に求めるための数值的方法を示す. まず，重心速度 $\dot{\boldsymbol{p}}_{G}$ は次のように表せる。

$$
\dot{\boldsymbol{p}}_{G}=\dot{\boldsymbol{p}}_{0}-\boldsymbol{R}_{0}^{0} \boldsymbol{p}_{G} \times \boldsymbol{\omega}_{0}+\boldsymbol{R}_{0}^{0} \dot{\boldsymbol{p}}_{G}
$$

ただし $\boldsymbol{p}_{0}$ は $\Sigma_{w}$ における基底リンクの位置， $\boldsymbol{R}_{0}$ は $\Sigma_{w}$ に対す る基底りンクの姿勢を表す $3 \times 3$ 行列， $\boldsymbol{\omega}_{0}$ は $\Sigma_{w}$ に対する基 底りンクの角速度, ${ }^{0} \dot{\boldsymbol{p}}_{G}$ は全身座慓系（基底リンクに固定され た座標系） $\Sigma_{0}$ に対する重心の相対速度である。

リンク $F$ が慣性系 $\Sigma_{w}$ に対し静止していることが既知である (例えば，右脚が支持脚であるとき，右足先リンクは $\Sigma_{w}$ に対し 静止している）ならば， $\boldsymbol{\omega}_{0}, \dot{\boldsymbol{p}}_{0}$ はそれぞれ次のように求まる (以降に扔いて, リンク $F$ を固定リンクと呼ぶ).

$$
\begin{aligned}
& \boldsymbol{\omega}_{0}=-\boldsymbol{R}_{0}^{0} \boldsymbol{\omega}_{F} \\
& \dot{\boldsymbol{p}}_{0}=-\boldsymbol{R}_{0}\left({ }^{0} \boldsymbol{p}_{F} \times{ }^{0} \boldsymbol{\omega}_{F}+{ }^{0} \dot{\boldsymbol{p}}_{F}\right)
\end{aligned}
$$

ただし ${ }^{0} \boldsymbol{\omega}_{F}$ は $\Sigma_{0}$ に対する固定りンクの相対角速度, ${ }^{0} \boldsymbol{p}_{F}$ は $\Sigma_{0}$ における固定リンクの位置である。 また ${ }^{0} \dot{\boldsymbol{p}}_{G}$ は次のように 表せる。

$$
{ }^{0} \dot{\boldsymbol{p}}_{G}=\frac{\sum_{i=0}^{n-1} m_{i}^{0} \boldsymbol{J}_{G, i} \dot{\boldsymbol{\theta}}}{\sum_{i=0}^{n-1} m_{i}}
$$

ただし ${ }^{0} \boldsymbol{p}_{G, i}$ は $\Sigma_{0}$ から見たリンク $i の$ 重心位置であり, ${ }^{0} \boldsymbol{J}_{G, i}$ は次式のように定義される。

$$
{ }^{0} \boldsymbol{J}_{G, i} \equiv \frac{\partial^{0} \boldsymbol{p}_{G, i}}{\partial \boldsymbol{\theta}}
$$

これは Orin ら [24]の方法を用いれば容易に求まる。式 (25) より， $\Sigma_{0}$ に対する相対的な重心ヤコビアン ${ }^{0} \boldsymbol{J}_{G}$ は次式のよう に定義できる。

$$
{ }^{0} \boldsymbol{J}_{G} \equiv \frac{\sum_{i=0}^{n-1} m_{i}{ }^{0} \boldsymbol{J}_{G, i}}{\sum_{i=0}^{n-1} m_{i}}
$$

式（23）（25）を式（22）に代入すれば，次式を得る.

$$
\begin{aligned}
\dot{\boldsymbol{p}}_{G} & =-\boldsymbol{R}_{0}\left({ }^{0} \boldsymbol{p}_{F} \times{ }^{0} \boldsymbol{\omega}_{F}+{ }^{0} \dot{\boldsymbol{p}}_{F}\right)+\boldsymbol{R}_{0}\left({ }^{0} \boldsymbol{p}_{G} \times{ }^{0} \boldsymbol{\omega}_{F}\right)+\boldsymbol{R}_{0}^{0} \boldsymbol{J}_{G} \dot{\boldsymbol{\theta}} \\
& =\boldsymbol{R}_{0}\left\{{ }^{0} \boldsymbol{J}_{G}-{ }^{0} \boldsymbol{J}_{F}+\left({ }^{0} \boldsymbol{p}_{G}-{ }^{0} \boldsymbol{p}_{F}\right) \times{ }^{0} \boldsymbol{J}_{\omega F}\right\} \dot{\boldsymbol{\theta}}
\end{aligned}
$$




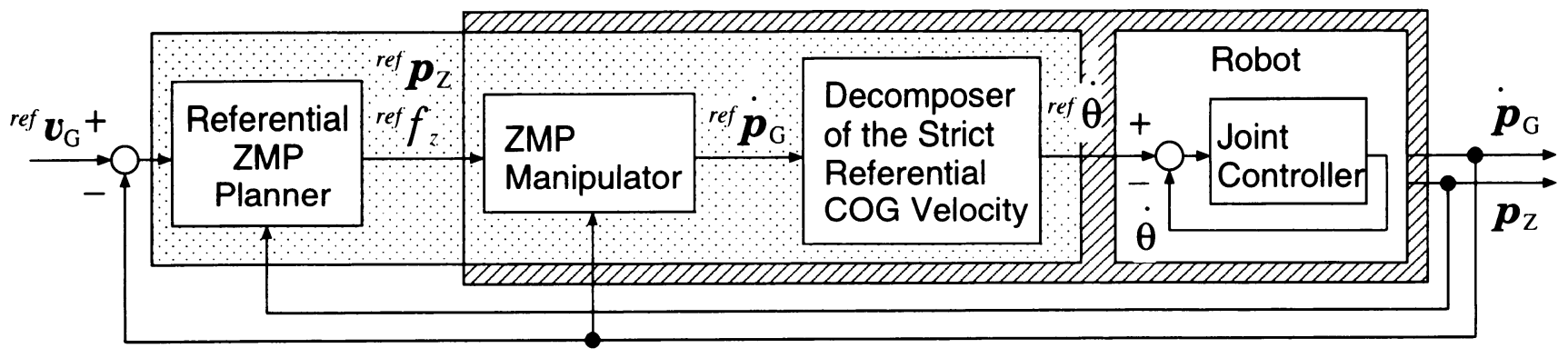

Fig. 3 Block diagram of the motion controller

ただし ${ }^{0} \boldsymbol{J}_{F}$ および0 $\boldsymbol{J}_{\omega F}$ は，それぞれ固定リンクの $\Sigma_{0} に$ に対す る相対的な並進速度ヤコビアンおよび角速度ヤコビアンであり， またここに限り $\left(\boldsymbol{p}_{G}-\boldsymbol{p}_{F}\right) \times$ は, $\boldsymbol{p}_{G}-\boldsymbol{p}_{F}$ との外積と等価な $3 \times 3$ 行列を表す.

結局, $\boldsymbol{J}_{G}$ は次式から求まる.

$$
\boldsymbol{J}_{G}=\boldsymbol{R}_{0}\left\{{ }^{0} \boldsymbol{J}_{G}-{ }^{0} \boldsymbol{J}_{F}+\left({ }^{0} \boldsymbol{p}_{G}-{ }^{0} \boldsymbol{p}_{F}\right) \times{ }^{0} \boldsymbol{J}_{\omega F}\right\}
$$

以上において，ロボットの運動による環境の変形の影響は無視 できると仮定していることになるが，多くの状況においてこれ は妥当であると考えられる。

\section{3 全身運動の生成}

ここでは重心に加速度 ${ }^{r e f} \ddot{\boldsymbol{p}}_{G}$ を与える全関節の目標運動を求 める方法について述べる。アクチュエータにより瞬間的に正確 に所望の加速度を与えることは実用上困難であるため，あらか じめ ${ }^{r e f} \ddot{\boldsymbol{p}}_{G}$ を 1 階積分七, 速度の目標值 ${ }^{r e f} \dot{\boldsymbol{p}}_{G}$ とする.

$$
{ }^{r e f} \dot{\boldsymbol{p}}_{G} \equiv \dot{\boldsymbol{p}}_{G}+\int_{\Delta t}^{r e f} \ddot{\boldsymbol{p}}_{G} d t
$$

ただし実際には，この間 ${ }^{r e f} \ddot{\boldsymbol{p}}_{G}$ が定数であると見なしてオイ ラー積分を用いる。 これは, 十分短い時間 $\Delta t$ で重心速度が $\dot{\boldsymbol{p}}_{G}$ から ${ }^{r e f} \dot{\boldsymbol{p}}_{G}$ に滑らかに変化し, その間の加速度が平均加速度 $\left({ }^{r e f} \dot{\boldsymbol{p}}_{G}-\dot{\boldsymbol{p}}_{G}\right) / \Delta t$ で比較的精度よく近似できることを期待して いるものである. ${ }^{r e f} \dot{\boldsymbol{p}}_{G}$ は次式のように，重心ヤコビアンを用 いて ${ }^{r e f} \boldsymbol{\theta}$ と関連づけられる。

$$
\boldsymbol{J}_{G}^{r e f} \dot{\boldsymbol{\theta}}={ }^{r e f} \dot{\boldsymbol{p}}_{G}
$$

またヒューマノイドによるタスク遂行においては，重心だけ でなく手足等の運動に課される拘束条件を同時に考慮しなけれ ばならない。それらを次式で表す。

$$
{ }^{r e f} \dot{\boldsymbol{p}}_{C}=\boldsymbol{J}_{C}{ }^{r e f} \dot{\boldsymbol{\theta}}
$$

式（31），(32）をまとめて次式のように表す.

$$
{ }^{r e f} \dot{\boldsymbol{p}}_{U}=\boldsymbol{J}_{U}{ }^{r e f} \dot{\boldsymbol{\theta}}
$$

結局，式（33）を満たすような関節角速度 ${ }^{r e f} \boldsymbol{\theta}$ を求めればよい。 大自由度系であるヒューマノイドロボットにおいてはこのよう な $^{r e f} \dot{\boldsymbol{\theta}}$ が一意に定まるとは限らない。ここでは式（33）を満た $す^{r e f} \dot{\boldsymbol{\theta}}$ のうち重み付き二乗ノルムが最小となるものを求めるこ とにする。これは次のように定式化できる。 $\frac{1}{2}\left\|{ }^{r e f} \dot{\boldsymbol{\theta}}\right\|_{\boldsymbol{W}}^{2} \rightarrow \min . \quad$ subject to $\boldsymbol{J}_{U}{ }^{\text {ref }} \dot{\boldsymbol{\theta}}={ }^{\text {ref }} \dot{\boldsymbol{p}}_{U}$

ただし， $\boldsymbol{W}=\operatorname{diag}\left\{w_{i}\right\}$ は重み行列である．また任意のベクト

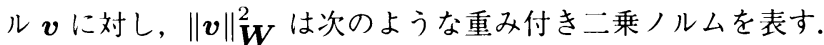

$$
\|\boldsymbol{v}\|_{\boldsymbol{W}}^{2} \equiv \boldsymbol{v}^{T} \boldsymbol{W v}
$$

問題（34）の解は次の方程式を解くことによって求まる。

$$
\left[\begin{array}{cc}
\boldsymbol{W} & \boldsymbol{J}_{U}^{T} \\
\boldsymbol{J}_{U} & \boldsymbol{O}
\end{array}\right]\left[\begin{array}{c}
r e f \\
\boldsymbol{\theta} \\
\boldsymbol{\lambda}
\end{array}\right]=\left[\begin{array}{c}
\mathbf{0} \\
r^{e f} \dot{\boldsymbol{p}}_{U}
\end{array}\right]
$$

ただし入は ${ }^{r e f} \dot{\boldsymbol{\theta}}$ の随伴ベクトルである。式（36）を実際に解 けば，次式を得る。

$$
{ }^{r e f} \dot{\boldsymbol{\theta}}=\boldsymbol{W}^{-1} \boldsymbol{J}_{U}^{T}\left(\boldsymbol{J}_{U} \boldsymbol{W}^{-1} \boldsymbol{J}_{U}^{T}\right)^{-1 r e f} \dot{\boldsymbol{p}}_{U}
$$

重み行列 $\boldsymbol{W}$ を適当に設定することで，各関節の重心加速度へ の寄与分を調整することができる。

\section{4 制御系の構成}

以上の方法を用いて設計される制御系は Fig. 3 のブロック線 四に示されるように，次の四つのサブシステムから成る。

1. 目標 ZMP 決定器：力学的拘束条件を考慮しつつ, 倒立振子 制御と同様の方法に基いて操作量としての目標 $\mathrm{ZMP}^{r e f} \boldsymbol{p}_{Z}$ および目標垂直床反力 ${ }^{r e f} f_{z}$ を決定する.

2. $\mathbf{Z M P}$ 操作器: 目標 $\mathrm{ZMP}^{r e f} \boldsymbol{p}_{Z}$ および目標垂直床反力 ${ }^{r e f} f_{z}$ と等価な重心加速度 ${ }^{r e f} \ddot{\boldsymbol{p}}_{G}$ (実際にはその積分值である $\left.{ }^{r e f} \dot{\boldsymbol{p}}_{G}\right)$ を算出する.

3. 速度分解器：重心に所望の ${ }^{r e f} \dot{\boldsymbol{p}}_{G}$ を与え, かつタスク遂行の ための拘束条件を満たすような関節角速度の目標值 ${ }^{r e f} \dot{\boldsymbol{\theta}}$ を 算出する。

4. 関節角速度制御器 : 関節ごとに局所フィードバック系を組み, 角速度制御を行う。

斜線でハッチングされている ZMP 操作器, 速度分解器, 関節角 速度制御器とロボットを含む部分が, 目標 ZMP 決定器によって 制御される倒立振子と等価なダイナミクスを有する．また実際 の制御器は，点でハッチングを施された部分により構成される.

$$
\text { 4. シミュレーション }
$$

提案した制御法を検証するため，いくつかの運動制御をシミュ レーション上で行った．想定したロボット [25]のモデルの外観， 関節配置，サイズおよび重量を Fig. 4 に示す。 
本章で行ったすべてのシミュレーションにおいて, 制御周期 $\Delta t$ は $0.001[\mathrm{sec}]$ とし, 問題 $(34)$ における重み $\boldsymbol{w}_{i}$ はすべて 1.0 とした。また，重心制御の他に式 $(32)$ に相当する次の拘 束条件孝加えた。

$$
\begin{aligned}
\boldsymbol{J}_{a r m}{ }^{r e f} \dot{\boldsymbol{\theta}} & =\mathbf{0} \\
\boldsymbol{R}_{0}{ }^{0} \boldsymbol{J}_{\omega L}{ }^{r e f} \dot{\boldsymbol{\theta}} & =\mathbf{0} \\
\boldsymbol{R}_{0}{ }^{0} \boldsymbol{J}_{\omega R}{ }^{r e f} \dot{\boldsymbol{\theta}} & =\mathbf{0} \\
\boldsymbol{J}_{R \rightarrow L}{ }^{\text {ref }} \dot{\boldsymbol{\theta}} & =\dot{\boldsymbol{p}}_{R \rightarrow L}+\int_{\Delta t} \boldsymbol{a}_{R \rightarrow L} d t
\end{aligned}
$$

ただし $\boldsymbol{J}_{a r m}$ は $^{r e f} \dot{\boldsymbol{\theta}}$ から腕関節角を抜き出す $8 \times 20$ 行列. ${ }^{0} \boldsymbol{J}_{\omega L}$, ${ }^{0} \boldsymbol{J}_{\omega R}$ はそれぞれ体幹から見た右足先リンク・左足先リンクの 角速度ヤコビアン． $\boldsymbol{J}_{R \rightarrow L}$ は右足から見た左足先の相対並進速 度ヤコビアンであり， $\boldsymbol{a}_{R \rightarrow L}$ は次式によって決定した。
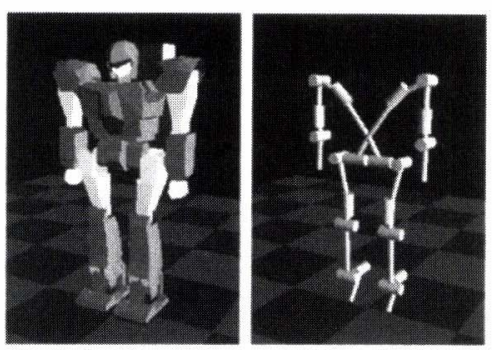

Number of Joints: 20 (8 for arms) (12 for legs)

height: $58[\mathrm{~cm}]$ weight: $6.5[\mathrm{~kg}]$

Fig. 4 Kinematic structure, size and mass of the robot

Table 1 PID gains for COG/feet position control

\begin{tabular}{c|lll}
\hline COG & $P_{x}=40$ & $I_{x}=10$ & $D_{x}=60$ \\
& $P_{y}=40$ & $I_{y}=10$ & $D_{y}=60$ \\
& $P_{z}=6000$ & $I_{z}=5000$ & $D_{z}=10000$ \\
\hline the left foot pos. & $P_{R \rightarrow L x}=10$ & - & $D_{R \rightarrow L x}=10$ \\
with repect to & $P_{R \rightarrow L y}=10$ & - & $D_{R \rightarrow L y}=10$ \\
the right foot pos. & $P_{R \rightarrow L z}=10$ & - & $D_{R \rightarrow L z}=10$ \\
\hline
\end{tabular}

$$
\boldsymbol{a}_{R \rightarrow L}=P_{R \rightarrow L}\left({ }^{r e f} \boldsymbol{p}_{R \rightarrow L}-\boldsymbol{p}_{R \rightarrow L}\right)-D_{R \rightarrow L} \dot{\boldsymbol{p}}_{R \rightarrow L}
$$

ただし $\boldsymbol{p}_{R \rightarrow L}$ は右足先から見た左足先位置, ${ }^{r e f} \boldsymbol{p}_{R \rightarrow L}$ はその目 標值, $P_{R \rightarrow L}, D_{R \rightarrow L}$ はそれぞれ比例・微分ゲインである. 式 （38）は腕の初期姿勢を維持すること, 式 (39)，（40）は体幹か ら見たおのおのの足先の初期姿勢を維持すること, 式 (41) は 右足先から見た左足先位置を目標值に収束させることをそれぞ れ意味する。実際に用いた制御ゲインを Table 1 に示す。

まず，両足での接地を維持しながら，おのおのの足の上に重 心を移動させる連動を行った、ロボットの前方，左方をそれぞ れ $x, y$ 軸の正方向とし, 右足先·左足先の初期位置はそれぞれ $\left[\begin{array}{lll}0.07 & -0.07 & 0\end{array}\right]^{T},\left[\begin{array}{lll}-0.07 & 0.07 & 0\end{array}\right]^{T}$ とした. 重心の水平方 向目標位置は適当なタイミングでおのおのの足の真上に交互に 切り替えた。また，重心の高さについては目標值を与えず，制 御は行わなかった。このときのスナップショットを Fig. 5 に， 重心と目標 ZMP および実 ZMP の軌跡を Fig. 6 にそれぞれ示 す。水平方向の運動については，重心を加速する方向と逆側に ZMP が回りこむ，いわゆるアンダーシュートが起こっており， 倒立振子と同じ原理で制御されている様子が確認できる。鉛直 方向の運動については陽に制御を行っていないため，時間の経 過と共に重心高さ変動幅が増大する傾向が見られるが，不自然 な拘束を受けず見た目に滑らかな動きが生成された。

次に，重心位置をまず右足真上に収束させ，それに伴い ZMP と右足先との距離が 0.04 以下になった時点で左足先に鉛直上 向きの初速度 $0.04[\mathrm{~m} / \mathrm{sec}]$ を与えた。その結果，左足が PD 制 御によって元の位置に引き戻される過程で Fig. 7 に示すような 片足昇降運動を行わせることができた。このときの重心と目標 ZMP および実 ZMP の軌跡を Fig. 8 に示す。左足を持ち上げ る際にZMP の摇動が生じたが, 支持領域内で収束し, 転倒す ることなく運動を継続できた。また，同じ運動を行わせ，左足を 上げた際に左向きに衝撃（2[N·sec] 程度の力積， 0.15 [sec] 間） を与えた。衝撃力を受けた瞬間に左足の左右方向の制御をやめ
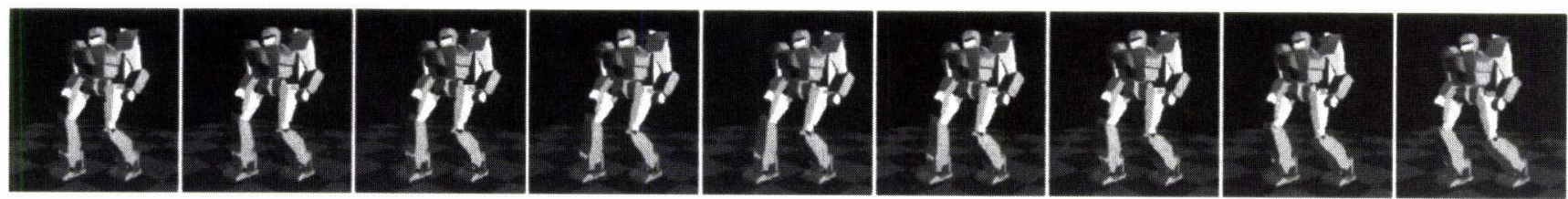

Fig. 5 A horizontal COG transportation motion
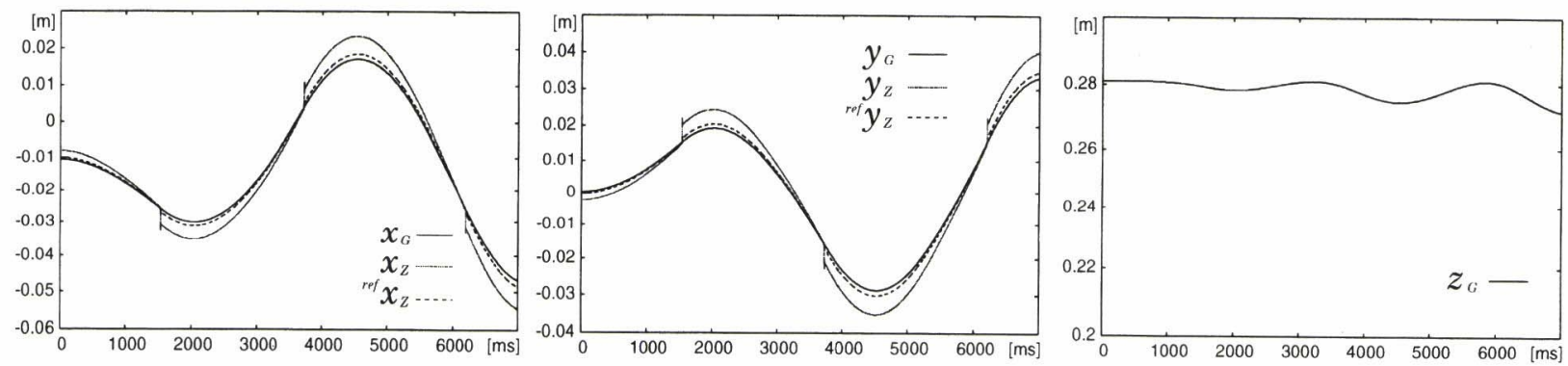

Fig. 6 Loci of COG and the referential/actual ZMP of the motion Fig. 5 

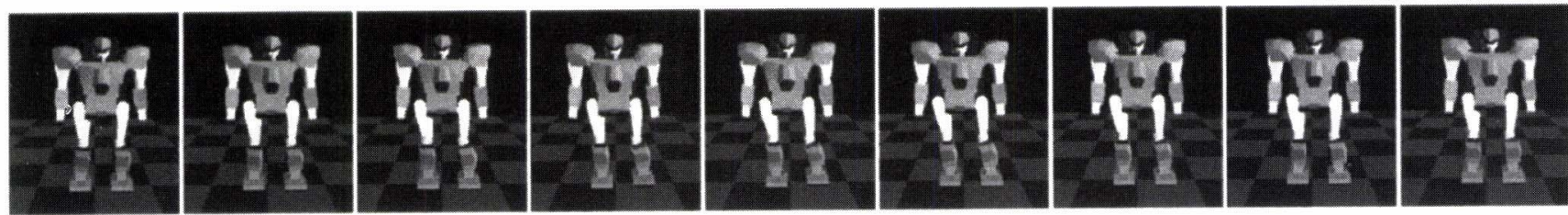

Fig. 7 One-foot stepping motion
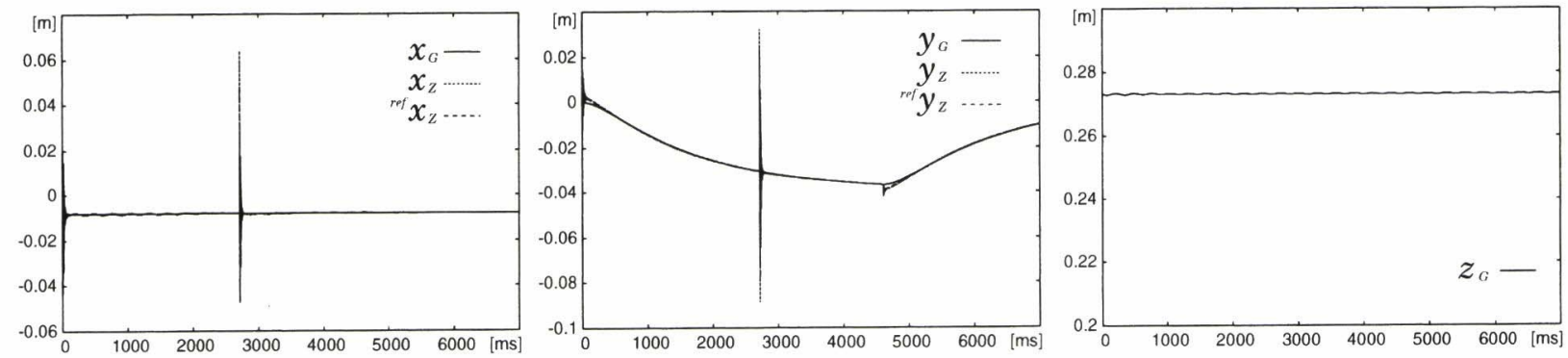

Fig. 8 Loci of COG and the referential/actual ZMP of the motion Fig. 7
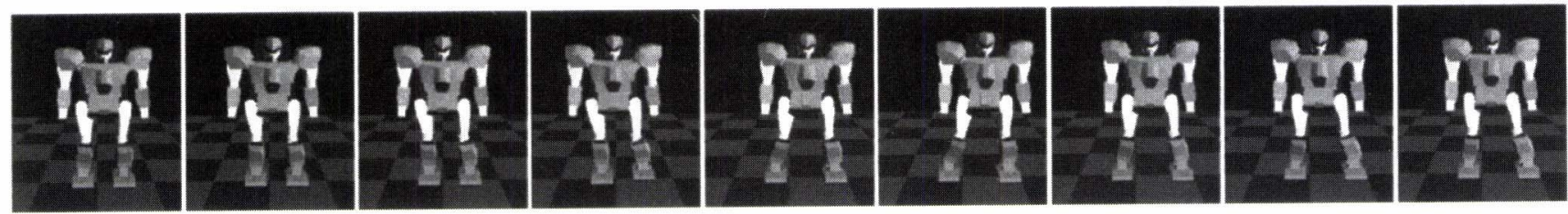

Fig. 9 A responsive motion against an impulsive perturbation during one-foot stepping
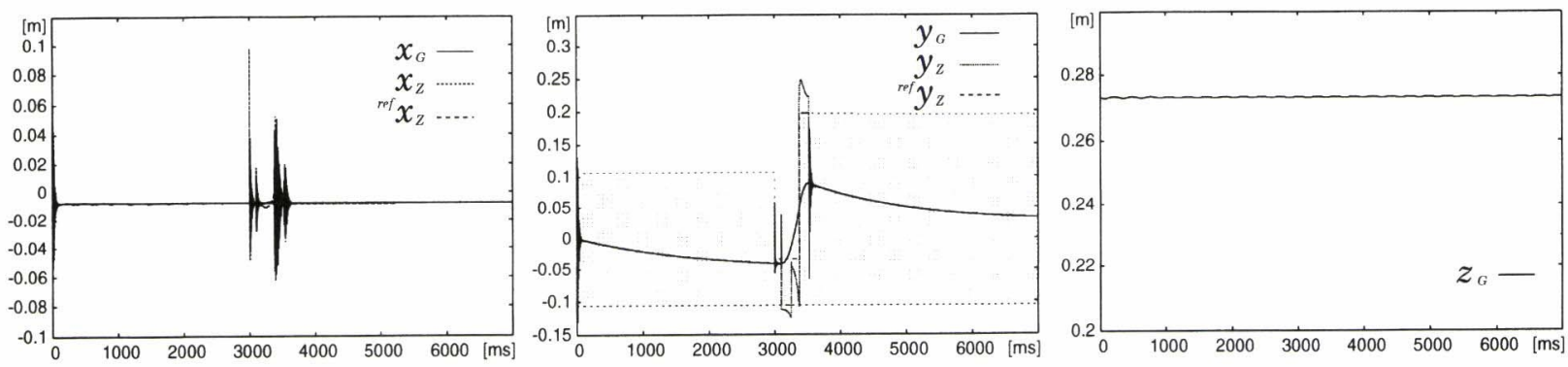

Fig. 10 Loci of COG and the referential/actual ZMP of the motion Fig. 9

ることで，衝撃を緩和する方向に自然に足を踏み出すような運 動が生成されたここのときのスナップショットをFig. 9 に, 重 心と目標 ZMP および実 ZMP の軌跡を Fig. 10 にそれぞれ示 す。左足を着くと同時に ZMP が大きく移動し, 重心を目標位 置に復帰させている様子か権察される。 $y$ 軸方向の運動に関す るグラフに执いて，点でハッチングした部分が設定支持領域に 相当する。目標 ZMP はこの領域内で飽和しているにもかかわ らず，実 ZMP は若干外部に出ている。これは式（4)，(5)に おいて無視した重心まわりに働くモーメントの影響によって才 フセットが生じるためと考えられる，支持領域は実際の接地多 角形よりも狭く設定してあるため転倒は免れたが，どの程度の 䛊差を許容できるのか，その考察は今後の課題である.
ZMP の乗っていない側の足に鉛直上方向・前方向の初速度を 与えれば，前方への踏み出し動作を行うことができる。これを 反復することで，Fig. 11 のような前進歩行を生成した，遊脚 踏み出し抢よび重心移動のタイミングは，次のような状態 I と 状態 II を反復するオートマトンによって決定した。すなわち， 状態 $\mathbf{I}$ ：重心を支持脚側に移動，ZMP と支持脚足先との距離が 0.025 以下になったら遊脚足先に初期速度 $\left[\begin{array}{lll}0.03 & 0 & 0.008\end{array}\right]^{T}$ を与え, 遊脚目標位置を前方に $0.16[\mathrm{~m}]$ 増加して状態 $\Pi$ へ. 状態 II : 重心南足先中点に移動, 遊脚足先が着床したら遊脚

と支持脚を交換して状態 $\mathrm{I}$ ○.

重心と目標 ZMP および実 ZMP の軌跡を Fig. 12 に示す。こ の結果は，提案する制御法を応用す扎ば，周期を陽に設定する 

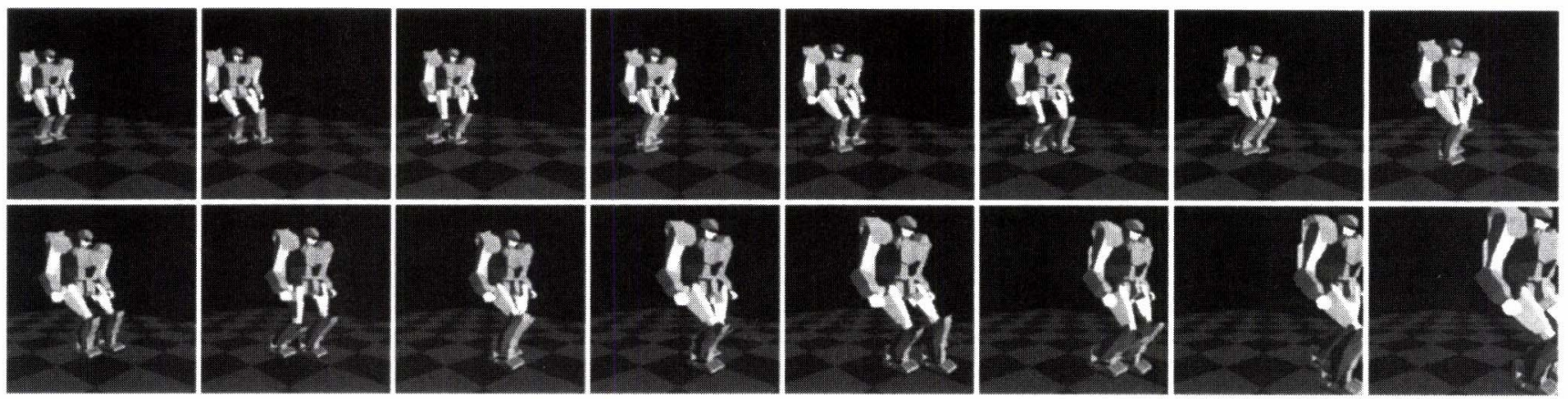

Fig. 11 A walking motion by repetitive forward steps
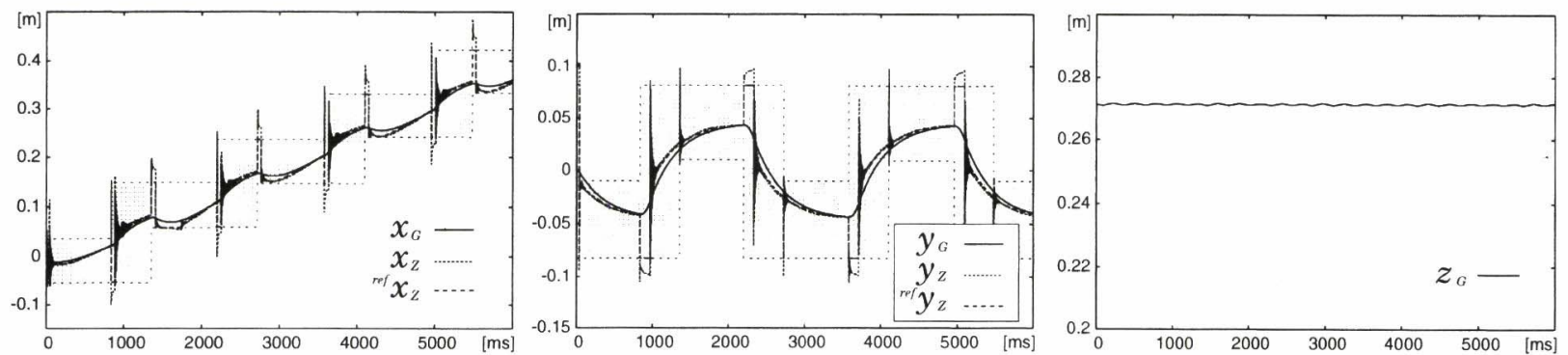

Fig. 12 Loci of COG and the referential/actual ZMP of the motion Fig. 11

ことなくほぼ定常的な歩行が実現できることを示唆している．

$$
\text { 5. おわりに }
$$

重心とZMP との関係を抽出した低次元モデルによって示さ れる，ヒューマノイドのダイナミクスが倒立振子のそれと等価 であるということに基づいて，ZMP 操作による重心制御法を提 案した。また重心やコビアンを用いて，低次元モデルと厳密な モデルとの間のギャップを比較的簡単に埋める万法を示し, シ ミュレーションを通して有效性を検証した。この結果得られた 利点は次のようなものである.

（1）ZMP 在操作量とすることで，慣性系に固定点在持たない ヒューマノイドに課される厳しい力学的拘束条件を直截的 に考慮することが可能となる。

（2）大自由度を持つヒューマノイドのダイナミックな運動を実 現するために，倒立振子制御と同じ方法を応用することが 可能になる。加速度レベルまで考慮した指令パターンを持 たず，重心や末端部位への位置・速度指令を適当に切り換 えるだけで，様々な運動を行うことができる。これは，パ ターンベーストな方法と比較して運動の目標値まわりの安 定化可能な範用が拡大されているということを意味し，大 きな衝撃等を受けたときのロバストな振舞いが期待できる.

（3）扔のおののリンクのダイナミクスを考虑した厳密な運動方 程式でなく，系全体の並進運動量に着目した大局的な運動 方程式を採用することで，計算コス卜を抑えられる。この ため，提案する方法はリアルタイム制御への適用に向いて いる，さらに重心ヤコビアンを用いて低次元モデルを実口 ボットに還元するので，ロボットの機構構造による制約が あまりない。

本稿に执いて, 重要な力学的拘束条件である摩擦力に関する
条件は考慮さ机ていない，接触面において十分な摩擦力を得ら れず滑りが生じる場合は，その重心運動への影響を何らかの形 でモデル化し，適応的に制御系を変更する必要があると考えら れる。これについては今後の課題としたい.

謝 辞 本研究は, 科学事業振興事業団 (JST) 戦略的基礎 研究推進事業（CREST）領域「脳老創る」の補助を受けた。

$$
\text { 参 考 文 献 }
$$

[1] 松井俊浩：“人間型ロボットはヒトに近づけるか”, 日本ロボット学会 誌, vol.15, no.7, pp.961-963, 1997.

[2] 中村仁彦, 山根克, 永嶋史朗: “構造変化走伴うリンク系の動力学計算 法とヒューマンフィギュアの運動計算”, 日本ロボット学会誌, vol.16, no.8, pp.1152-1159, 1998.

[3] M. Vukobratović, B. Borovac, D. Surla and D. Stokić: 'Biped Locomotion: Dynamics, Stability, Control and Application,' Scientific Fundamentals of Robotics. vol.7, Springer-Verlag, 1990.

[4] 山口仁一, 高西淳夫, 加藤一郎：“上体運動により 3 軸モーメントを 補償する 2 足歩行ロボットの開発”, 日本ロボット学会誌, vol.11, no.4, pp.581-586, 1993.

[5] K. Hirai, M. Hirose, Y. Haikawa and T. Takenaka: "The Development of Honda Humanoid Robot," Proceeding of the 1998 IEEE International Conference on Robotics \& Automation, pp.1321-1326, 1998.

[6]長阪憲一郎：動力学フィルタによる人間型ロボットの全身運動生成, $\mathrm{PhD}$ thesis, 東京大学大学院工学系研究科, 2000.

[ 7 ] S. Kajita, O. Matsumoto and M. Saigo: "Real-time 3D walking pattern generation for a biped robot with telescopic legs," Proceedings of the 2001 IEEE International Conference on Robotics \& Automation, pp.2299-2036, 2001.

[8] K. Löffler, M. Gienger and F. Pfeiffer: "Sensor and Control Design of a Dynamically Stable Biped Robot," Proceedings of the 2003 IEEE International Conference on Robotics \& Automation, pp.484-490, 2003.

[9] R.B. McGhee, F. Gubina and H. Hemami: "On the dynamic 
stability of biped locomotion," IEEE Transactions on BioMedical Engineering, vol.BME-21, no.2, pp.102-108, 1974.

[10] 宮腰清一, 多賀笽太郎, 國吉康夫, 長久保晶彦：“神経振動子を用い た三次元 2 足足踏みシミュレーションーヒューマノイドの実世界内 行動を目指して—”, 日本ロボット学会誌, vol.18, no.1, pp.87-93, 2000.

[11] G. Pratt and J. Pratt: "Exploiting natural dynamics in the control of a planar bipedal walking robot," Proceedings of the 36 Annual Allerton Conference on Communication, Control, and Computing, 1998

[12] A. Kawamura and Y. Fujimoto: "Simulation of an Autonomous Biped Walking Robot Including Environmental Force Interaction," IEEE Robotics \& Automation Magazine, vol.5, no.2, pp.33-41, 1998.

[13] 池田貴幸, 篠原隆之, 美多勉：“可変拘束制御を用いた三次元脚式口 ボットの走行制御”, 日本ロボット学会誌, vol.21, no.1, pp.94-102, 2003.

[14] M. Vukobratović and J. Stepanenko: "On the Stability of Anthropomorphic Systems,” Mathematical Biosciences, vol.15, no.1, pp.1-37, 1972.

[15] 空尾謙嗣, 村上俊之, 大西公平：“ZMP と重心制御の融合による 2 足歩 行ロボットの安定動歩行”, 電気学会産業計側制御研究会, pp.35-40, 1997.

[16] 小幡智, 藤本康孝, 河村篤男: “ZMP 制御に基づく 2 足歩行ロボット制 御”, ロボティクス・メカトロニクス講演会'99 講演予稿, 2A1-41-063, 1999.

[17] 竹内裕喜：“脚式ロボットのリアルタイム最適化と制御”，ロボティク ス・メカトロニクス講演会’02 講演予稿, 2P1-E11, 2002.

[18] 水戸部和久, 矢島克知, 那須康雄 : “ゼロモーメント点の操作による歩 行ロボットの制御”, 日本ロボット学会誌, vol.18, no.3, pp.359-365, 2000.

[19] 加藤一郎：“二足歩行ロボットーその歴史と課題—”, 日本ロボット 学会誌, vol.1, no.3, pp.164-166, 1983.

[20] 有本卓, 宮崎文夫：“二足歩行ロボットの階層制御”, 日本ロボット学 会誌, vol.1, no.3, pp.167-175, 1983.

[21] T. Sugihara, Y. Nakamura and H. Inoue: "Realtime Humanoid Motion Generation through ZMP Manipulation based on Inverted Pendulum Control," Proceedings of the 2002 IEEE International Conference on Robotics \& Automation, pp.14041409, 2002.

[22] 平野毅, 河村篤男：“適応インピーダンス制御による人間型 2 足口 ボットの跳躍動作”，電気学会産業計測制御研究会資料, pp.137-142, IIC-99-22, 1999.

[23] 田宮幸春, 稲葉雅幸, 井上博允：“人間型ロボットの片足立脚動作に おける全身を用いた実時間動バランス補償”，日本ロボット学会誌， vol.17, no.2, pp.268-274, 1999.

[24] D.E. Orin and W.W. Schrader: "Efficient Computation of the Jacobian for Robot Manipulators," The International Journal of Robotics Research, vol.3, no.4, pp.66-75, 1984.

[25] 杉原知道，中村仁彦：“高機動性獲得に向けた運動制御実験のための 小型ヒューマノイドロボットの開発”, 第 21 回日本ロボット学会学 術講演会予稿集, 2A24, 2003

[26] 北川知伸, 長阪憲一郎, 西脇光一, 稲葉雅幸, 井上博允: “遺伝的了 ルゴリズムを用いた人間型ロボットの脚腕協調動的起立動作の生成”, 第 17 回日本ロボット学会学術講演会予稿集, pp.1191-1192, 1999.

\section{付録 A. 台車型倒立振子の運動方程式}

Fig. 13 に示すような平面内に拘束された台車型倒立振子の 運動方程式は, 台車の質量が無視でき理想的に時間遅れなしで 任意の位置に制御できるという仮定の下，次式で表される。

$$
\ddot{\theta}=\frac{g}{l} \sin \theta-\frac{\ddot{x}_{c}}{l} \cos \theta
$$

ただし $\theta$ は倒立振子と鉛直軸とのなす角， $l$ は軸長， $x_{c}$ は水平 軸上の支持点の座標である. 先端位置 $[x, z]$ は次式で表される.

$$
\begin{aligned}
& x=x_{c}+l \sin \theta \\
& z=l \cos \theta
\end{aligned}
$$

式（A.2)，(A.3）を式（A.1）に代入すると次式のようになる.

$$
\ddot{\theta}=\frac{g}{l}\left(\frac{x-x_{c}}{l}\right)-\frac{\ddot{x}_{c} z}{l^{2}}
$$

また，式（A.2）（A.3）を $\theta \simeq 0$ の近傍で線形化すると，

$$
\begin{aligned}
& \theta \simeq \frac{x-x_{c}}{l} \\
& z \simeq l
\end{aligned}
$$

これを式（A.4）に代入し整理すれば，次式を得る.

$$
\ddot{x}=\omega^{2}\left(x-x_{c}\right)
$$

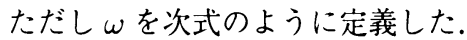

$$
\omega^{2} \equiv \frac{g}{l}
$$

\section{付録 B. 仮想水平面（VHP）}

ヒューマノイドロボットと環境との接触点は三次元的に分布 し，一般に床面上の点とされる ZMP の力学的整合条件をそのよ うな空間上の領域に関して議論するのは困難である．北川ら [26] は，接触群から任意の 3 点を選んで面を張り，その上に定義され る拡張 ZMP を用いて脚腕協調運動の軌道を計画する方法を提 案した．しかし望ましい運動を得るための面の選択の仕方は自

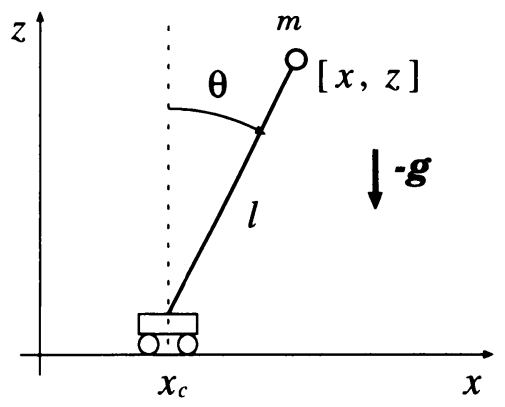

Fig. 13 Inverted pendulum

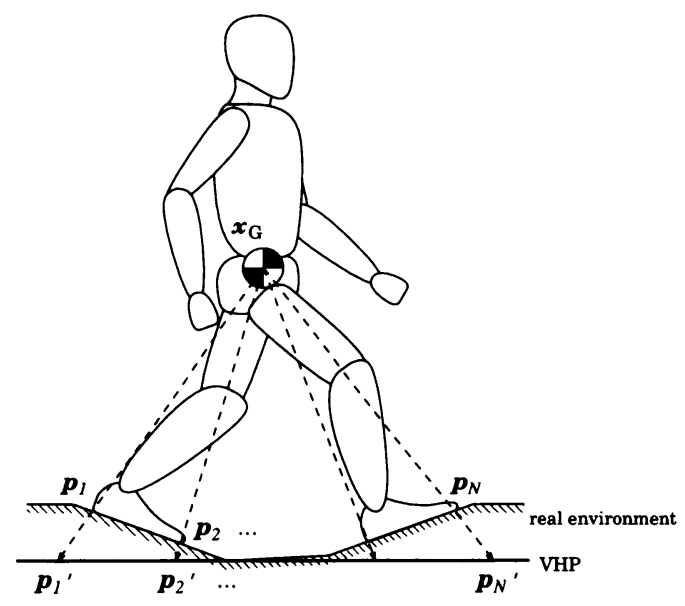

Fig. 14 VHP (Virtual Horizontal Plane) 
明ではなく，考えられるすべての組み合わせについてこれを確 認するのは計算量の観点からも不利である。本研究では，すべて の接触点を，仮想的に設定したある水平面（Virtual Horizontal Plane, VHP [21]）上の, 重心に及ぼす力に関して等価な点に 投影し, 三次元的な接触を統一的に考慮する方法を導入する。慣 性力の影響を無視したとき，力ベクトルが作用線上で平行移動
できることに注意すれば，Fig. 14 に示すような重心と接触点 とを結ぶ直線とVHP との交点が等価接触点となる。これらの 凸包をVHP 上の等価接地多角形と定義すれば，接触点が同一 平面上にない場合でも, ZMP の力学的許容性を VHP 上で議 論することが容易になる。

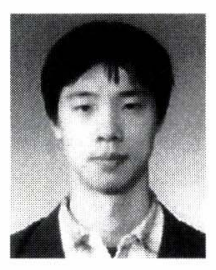

杉原知道（Tomomichi Sugihara）

1975 年 4 月 9 日生. 1999 年東京大学工学部機械 情報工学科卒業, 2004 年同大学大学院情報理工学 系研究科知能機械情報学専攻博士課程修了. 現在, 同大学大学院情報理工学系研究科知能機械情報学専 攻助手. 博士 (情報理工学) 、ヒューマノイドロボッ トの運動学, 力学, 制御, ハードウェア設計, およ び実世界ロボットと仮想世界エージエントの統合的制御システムアー キテクチャやソフトウェア等の研究に従事. IEEEの会員.

(日本ロボット学会正会員)

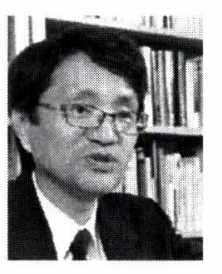

中村仁彦 (Yoshihiko Nakamura)

1954 年 9 月 22 日生. 1982 年京都大学大学院工学 研究科精密機械工学専攻博士課程退学, 同年より 1987 年まで同大学助手. 1987 年より 1991 年 3 月 までカリフォルニア大学サンタバーバラ校助教授, 準教授. 同年 4 月より東京大学に勤務. 現在, 同大 学大学院情報理工学系研究科知能機械情報学専攻教 授. 工学博士. ロボットの運動学, 動力学, 制御, および知能の問題, 特に非ホロノミックロボット, 脳型情報処理, ヒューマノイドや CG の運動・力学計算, 外科手術用ロボットなどの研究に従事. 計測自動 制御学会, システム制御情報学会, 日本機械学会, 日本コンピュー夕 外科学会, IEEE, ASME などの会員. (日本ロボット学会正会員) 